\title{
Argumentation (Jadal): An Inevitable Method of Expression in the Qur'ān: Purpose and Aims
}

\author{
Muhammad Kamal-Deen Bello \\ Department of Religious Studies, Faculty of Arts, National Open University of Nigeria (Noun), Abuja, Nigeria \\ *Corresponding Author: Muhammad Kamal-Deen Bello, Department of Religious Studies, Faculty of \\ Arts, National Open University of Nigeria (Noun), Abuja, Nigeria
}

\begin{abstract}
Jadal or Jidāl or Muhājjah (argumentation) is a controversial issue that different writers, both Muslims and non-Muslims among them have divergent opinions upon. To some writers, argument (Jadal) is permissible in Islam, to some; it is prohibited that a true Muslim must not embark on. With this submission, some are seen to be liberal, while some are seen to be extremists, because, they went to say that the whole Qur'ān is being dominated by the argumentative methods of expression and rational reasons. Whatever may be the case, the holy Qur'ān embarks on argumentation as a style of expression in propagating the teachings of its religion. Hence, the Qur'anic argumentative method is not for joke, play and fun, but rather, it has significant purposes and aims that it sets aside to be achieved that this paper aims at highlighting it for discussion in due course.
\end{abstract}

Keywords: Jadal, Qur'ān, Aims and Purposes.

\section{INTRODUCTION}

Argumentation (Jadal) is a human being natural phenomenon that some writers have divergent opinions on its connotation and definition. It is an ambiguous term that majority of people do not know how they can perceive its position in Islam, to the extent that, some kicked against it and pronounced its total prohibition and condemnation in the Qur'ān. Though, some do not oppose it, but, they differ in weather it is an obligatory act that Muslims should embark upon, or it is permissible or allowed based on the circumstances and situations surrounding it. However, the holy Qur'ān applies the method of argumentation (argumentative method) to convince people on its mission. It also applies it to disperse and convey its message to the entire world. Not only this, but, Jadal has significant role, purposes and aims in disseminating Islamic teachings in the Qur'ān.

First and foremost, it is worthy of notice that the holy Qur'ān points at Jadal as a natural phenomenon to all mankind in general. It declares that:

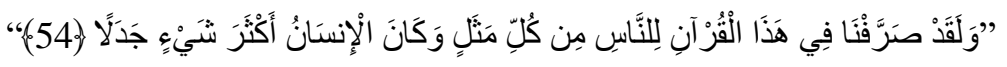

Meaning: "In this Qur'ān we have presented every kind of description for people but man is more contentious than any other creature."

The above verse declares that, Jadal is natural to human beings. That is, if something is unclear to him, he started searching and investigating such thing in order to know the thing in its actual picture and real form. Sometimes, this may take man to be arguing or rather questioning such thing, why it must be this and how it cannot be this? ${ }^{2}$ As a result of this, the Qur'ānic verse quoted above should not be translated to mean, conflict and dispute, as suggested by al-Hilālī and Khān: “...But man is ever quarrelsome than anything". ${ }^{3}$ Man is not in any way a fighter or troublesome, that is trouble

\footnotetext{
${ }^{1}$ Abdel Haleem, M.A.S. 2004. The Qur'ān. New York: Oxford University Press. p. 187. Al-Qur'ān.Al-Kahf 18: 54.

${ }^{2} \mathrm{Li}^{\mathrm{c}}$ asakir, Y. U. 2005.Al-Jadal F̄̄ al- Qur'än-Khașā̉ișuhuWadilälātuhu. M. A. Dissertation. Algeria University: p. 15.

${ }^{3}$ Al-Hilālī\&Khān,1404H. The Noble Qur'ān: English Translation of the Meanings \&Commentary. K.S.A. Madinah, King Fahd: p. 393.
} 
maker, but, rather, he is opposing ${ }^{4}$ or preferably, man is contentious, as in translation of Abdel Haleem mentioned above, to mean, man too likes argument, especially, when a particular thing remains ambiguous or unclear and mysterious to him. In actual sense, if man is quarrelsome, then, it should be some of them and not all. Meaning that, man in his argument over a particular thing, he always aims at convincing others or he himself be contended with the submission of others. ${ }^{5}$ Hence, it will be erroneous to perceive Jadal as quarrel, fighting and conflict; rather, it is an attempt to support a claim or assertion by providing a reason or reasons for accepting it. ${ }^{6}$ IbnManzūr (1412 A.H./1992 C.E.) also upheld this view in one of his suggested literal meanings for Jadal, when he says: مقابلة meaning that, argument is an exchange of evidence. Or as it will be vividly clear in another term normally use for argumentation, that is Muhāijjah in the Qur'ān, to mean "winning with evidence and proofs".?

Apart from this, scholars like ${ }^{c}$ Abdullahi bin ${ }^{c}$ Umar, Hassan Basri, Imams Mālik and Ahmad, alQayrawanī, Amīn ash-Shinqītietc were reported to dislike argumentation ${ }^{8}$ for the mere fact that the mutakallamūn had once in time misused its method. ${ }^{9}$ Of course, the mutakallimūn talked too much on necessary and unnecessary issues that nearly closed to shake the faith of some Muslims, if care was not taken and if someone's faith was not firmed. Other writers are so serious with the matter and denounced or condemned the existence of Jadal out rightly. They further explained that the holy Qur'ān prohibits it. According to them, in giving reasons for such assumption, it is observed that, the word Jadal and its derivatives like Jidāl, Yujādiletc are used randomly in the whole Qur'ān for twenty-six (26) times only. However, it is used for quite number of twenty-one (21) times to represent reprehensible or condemnable argument, while, it is used only in five (5) different places, to translate and inform laudable or commendable one. ${ }^{10}$ As a result of this, they scare away from any discussion that will evolve argumentation. Couple with total condemnation and prohibition given to the attitude (argumentation) by the Qur'ān, for the Muslims while on Hajj (pilgrimage) that they must stay away from Jidal throughout the period of pilgrimage, where Allah says:

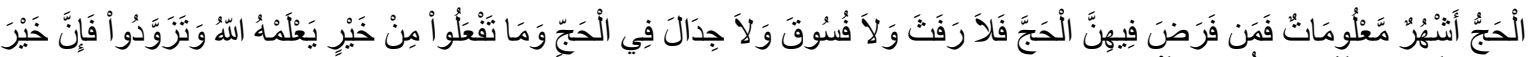

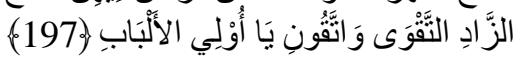

"The pilgrimage takes place during the prescribed months. There should be no indecent speech, misbehavior, or quarrelling for anyone undertaking the pilgrimage". ${ }^{11}$

In summary, Abu Ameenah Philip in his book "Usool al-Tafseer" profoundly submits that the Qur'ān is full of cohesive argumentative reasons and rationales. ${ }^{12} \mathrm{AbdusSalam}^{13}$ also testifies to this fact and submits that Islam is a religion of communication and conversation (ḥiwār) evidencing ('Iqnā') and convincing ('Iqtin̄à') and one of the methods of its evidencing and convincing is argumentation (i.e. Jadal or Muhājjjah). Meanwhile, argumentation is real and it has bases in the holy Qur'ān and in the prophetic traditions (ahāaīth) as well. It is also considered to be important that, the Prophet Muhammad and other prophets of Allah applied the method as they were asked to embark on it in calling people to the way of Islam, simply, because of its importance and purposes that will be discussed soonest in this paper.

\section{Purposes of QuR'ĀNic Argumentation (JADAl)}

\footnotetext{
${ }^{4}$ Vicker, A. S. (trans.) 1999.Interpretation of the Meaning of the Glorious Qur'ān.Malaysia.Kuala Lumpur.TR Group of Company: p. 357.

${ }^{5} \mathrm{Ibn}^{\mathrm{c}}{ }^{A}$ šūr, M.T. 1984.At-TahrīrWat-Tanwīr. Vol.1. Ad-DārAt-Tunisiyyah: p. 349.

${ }^{6}$ Richard, P. 2004. Critical Thinking. $7^{\text {th }}$ Edition. Chico, Calfornia State University: p. 5.

${ }^{7}$ IbnManẓūr, 1412H/1992M.Lisānul- ${ }^{\mathbf{c}}$ Arab. ${ }^{\text {st }}$ Edition.Vol. 2. Lebanon.Beirut.Dār-Ṣādir: p. 228.

${ }^{8}$ Al-' Uthmān, H. I. 1425H/2004M.Uṣūl al-Jadal Wal-MunāzarahFil-KitābWassunnah.DārIbnHazm: pp. 138162.

${ }^{9}$ Ibid. p. 135.

${ }^{10}$ Al-Qayn, G. A. S. (1427H/2006M).Adabul-HiwārFil-Islam. $1^{\text {st }}$ Edition. Lebanon. Beirut.Darul-Ma ${ }^{c}$ rifah: pp. 29-36 and Jarīshah, ${ }^{\mathrm{c}}$ A.(1412H/1991M).Adabul-HiwārWal-Munāzarah.2nd Edition.Dārul-Wafā': p. 28.

${ }^{11}$ Abdel Haleem(trans.) 2004.p. 22.A.1-Qur'ān.Baqarah 2: 197.

${ }^{12}$ Abu Ameenah, B.P. September, 1997.Usool Al-Tafseer. Sharjah: p. 5.

${ }^{13}$ AbdusSalam, J. 2002.Al-Islam...Wa-Hiwā̄r al-Hadarāt, Vol.2, Dārul-Bayān, p. 9.
} 
Without any reasonable doubt, Allah (SWT) in the Qur'ān enters into argumentation and uses the argumentative method to launch some facts. Not only that, He (Allah) also instructs severally commands many of His prophets to embark on the method in propagating and disseminating the messages of Islam to the entire world and to their various and different communities in particular for certain reasons and rationales or purposes as it will be later discussed. ${ }^{14}$

\subsection{Argument as Natural Phenomenon}

As said earlier, argument is a natural characteristic of human beings, to the extent that both genders; male and female, old and young and responsible and irresponsible or righteous and unrighteous embark on it. Qur'ān says while addressing the Muslims and blaming the non-believers:

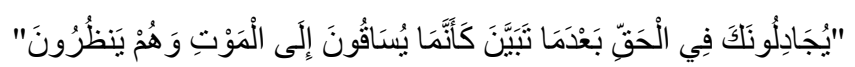

Meaning: "..and argued with you about the truth after it had been made clear, as if they were being driven towards a death they could see with their own eyes." 15

The expression there involves argumentation "argued" and its word that is used is "Jadal" in plural form (Yujädilünak), to show that everyone is applying argumentative method without any exemption. It is on the female argumentation that the Qur'ān gives this illustration thus:

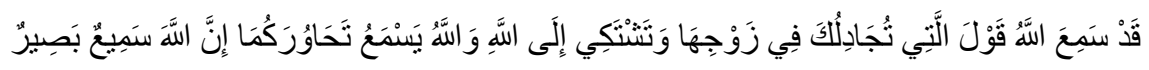

Meaning: "God has heard the words of woman who disputed with you [Prophet] about her husband and complained to God: God has heard what you both had to say. He is all hearing, all seeing."16

If this is the fact on the side of mankind in general that, he will not submit and surrender gently and amicably to every things, but, only after some clarifications, proofs and evidences, then, there is a need for argumentative method in the Qur'ān for smooth digestion and proper comprehension of its messages by the majority audience and readers. After all, the method seems to involve objectivity that man likes and not coercion that he hates. Co-incidentally, Islam discourages or rather prohibits coercion and compulsion of the religion. ${ }^{17}$ It is on this natural phenomenon that argument is to the generality of human beings makes $\mathrm{Li}^{\mathrm{c}}$ asākir to submit that:

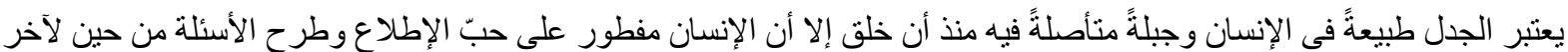

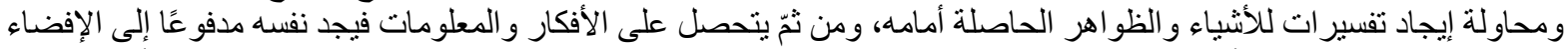

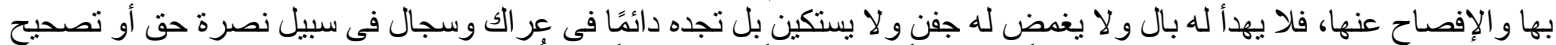

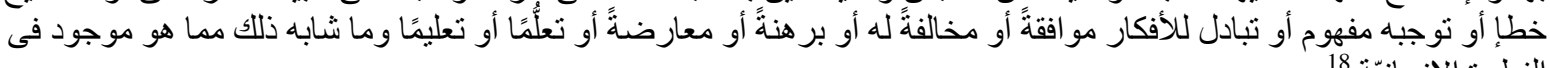

$$
\begin{aligned}
& \text { الفطرة الإنسانيّة. } 18
\end{aligned}
$$

Meaning: Argumentation (Jadal) is regarded to be natural to human beings. It is programmed in him right from beginning of his creation that he too likes to know, to ask and to look for explanation about all what is seen or appeared before him or what is going in his surrounding and environment. He will not rest his mind and relent efforts until he has clear picture and understanding about many things he sees and observes. Later on, he (man) is now found in taking position in supporting truth or correcting a mistake. Likewise, his understanding towards things will prompt him to want to share ideas positively or negatively or give evidence and proofs to back or antagonize or to want to learn or teach and all of what are view as in the human natural being and creation. However, this is the best way to interpret the Qur'ānic phrase that says:

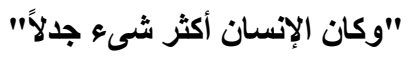

Meaning: "However, man is, above all else, always given to contention"19

Though, this interpretation may be in contrary to the stances of many mufassirūn. For example, AlQurtubi ${ }^{20}$ upheld that the verse or the phrase was revealed in regarding to the case of an-Nadr bin al-

\footnotetext{
${ }^{14}$ Al-Bayānūniyy, M. A. F. 1411H.Al-Madkhal 'Ilā' Ilm Ad-Da ${ }^{\boldsymbol{c}}$ wah. Mu'assasatAr-Risālah: pp. 265-266.

${ }^{15}$ Abdel Hakeem (trans.) 2004.p. 110.Al-Qur'ān. Al-'Anfāl8: 6.

${ }^{16}$ Ibid. p. 363.Al-Qur'ān. Al-Mujādalah 58: 1.

${ }^{17}$ Ibid. Al- Baqarah 2: 256.

${ }^{18} \mathrm{Li}^{\mathrm{c}}$ asākir.p. 15 .

${ }^{19}$ Asad Muhammad (trans.) 2013.The Message of The Qur'ān. Kuala Lumpur. Islamic Book Trust.p. 535. AlQur'ān Kahf 18: 54.
} 
Hārith who argued about the Qur'ān. Or, it was revealed in the case of 'Ubayy bin Khalf, or according to az-Zajjāj, it was revealed in case of the unbelievers whose usually argue badly and ironically. But the word "al- 'Insān" is general and above individual person or group of unbelievers alone.

In addition to that, Abus-Su ${ }^{c} \bar{u} d$ and $\mathrm{Ibn}^{\mathrm{c}} \overline{\mathrm{A}} \operatorname{shu} \mathrm{r}^{21}$ in their books of tafsīir interpret the verse to mean that man too likes negative or reprehensive argumentation (al-Jadal al-Bātil) and quarrel. But $\mathrm{Ibn}^{\mathrm{c}} \overline{\mathrm{A}} \mathrm{shū}$ in another meaning given to the verse submitted that it is the nature of human to always try to get his opponent convinced about his stance and position on certain issue. ${ }^{22}$ According toSayyidQutb, the meaning ofthat Qur'ānic phrase is, man too likes argumentation than any other beings and creatures. ${ }^{23}$

\subsection{Allah's Commandment/ Involvement in Argumentation in the Qur'ān}

It is an inevitable fact that, Jadal is a subject and method at same time that the Most Knowledgeable, Allah encourages it or even commands Muslims to always embark on it in calling people to Allah's straight way, Islam and Qur'ān. Allah says:

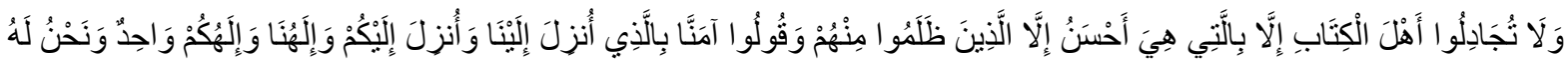

$$
\begin{aligned}
& \text { مُسنْلمِونَ. }
\end{aligned}
$$

Meaning: "[Believers], argue only in the best way with the People of the Book, except with those of them who act unjustly. Say, 'We believe in what was revealed to us and in what was revealed to you; our God and your God are one [and the same]; we are devoted to Him'." ${ }^{24}$ Prophet Muhammad in particular was confronted with the following directives and commandment that, he should engage in argumentation with the pagans, Christians and Jews in his $\mathbf{d a}^{\mathbf{c}} \mathbf{w a h}$. Allah says:

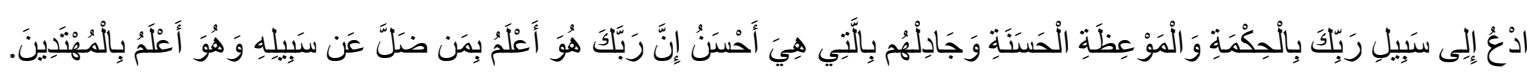

Meaning: "[Prophet], call people to the way of your Lord with wisdom and beautiful teaching. Argue with them in the most courteous way, for your Lord knows best who has strayed from His way and who is rightly guided." 25

Verily, argumentation is in the third method of $\mathbf{d a}^{\mathbf{c}} \mathbf{w a h}$ that the Qur'ān calls attention of a preacher (dā $\mathbf{c}$ iyah) to, besides al-ḥikmah (wisdom) and maw'izahạasanah (i.e. good admonition). In short and first of all, Allah (SWT) personally entered into an argument with the angels at the point of creation of Ādam over his vicegerency on this global earth in particular and over the concept of Khilāfah of mankind in general. Qur'ān reports the argumentation thus:

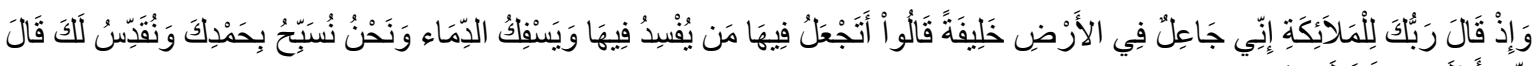

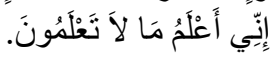

Meaning: 'Behold [Prophet], when your Lord told the angels, 'I am putting a successor on earth,' they said, 'How can You put someone there who will cause damage and bloodshed when we celebrate Your praise and proclaim Your holiness?' but He said, 'I know things you do not'." ${ }^{26}$ No doubt in the fact that, there is tune of argumentation in the above verses. Because, the response of the angels serve as an evidence for kicking against the creation of Ādam. After all, almost all the writers including mufassirūn consider their response to be "istifhāminkārî", that is an interrogative and argumentative statement or exclamatory statement. ${ }^{27}$ This submission is testifying to the fact that, there is tune of argumentation in the verses, as mentioned before. Above all, $\mathrm{Li}^{\mathrm{c}} \mathrm{Asākir}$ submits that:

\footnotetext{
${ }^{20}$ Al-Qurțubi $\quad$ 1427H/2006M.Al-Jāmi Li'Ahkām Al-Qur'ān. Abdul-Muhsin $\quad$ A.A. (ed.). Vol.1. $3^{\text {th }}$ Edition.Lebanon. Beirut. Mu'assasatAr-Risālah: p. 309

${ }^{21}$ Abus-Su ${ }^{c} \bar{u} d$, M. 1391H/1971M.TafsīrAbis-Su ūd. ${ }^{c}$ Ațā, A.Q.A. (ed.). Vol.3. Riyadh.Maktabat Riyadh AlHadīthah.p. 532 and $\operatorname{Ibn}^{\mathrm{c}} \overline{\mathrm{A}} \mathrm{shūr}$ 1984M.Vol. 15.p. 347.

${ }^{22} \mathrm{Ibn}^{\mathrm{c}} \overline{\mathrm{A}}$ shūr 1984M.Vol. 15.p.349.

${ }^{23}$ Sayyid,Quṭb 1417H/1996M.FīZilāl Al-Qur'ān.25 ${ }^{\text {th }}$ Edition.Vol. 4.Cairo. Dārush-Shurūq: p. 2275.

${ }^{24}$ Abdel Hakeem 2004. p. 255.Al-Qur'ān.Al- ${ }^{\mathrm{c} A n k a b u ̄ t ~ 29: ~} 46$.

${ }^{25}$ Ibid.p. 174.Al-Qur'ān. An-Naḥl 16: 125.

${ }^{26}$ Ibid. p. 7.Al-Qur'ān.Baqarah 2: 30.

${ }^{27}$ Ibid.p. 7 and Sharqāwī, H. (nd.).Al-Jadal Fil-Qur'ān. Alexandra. Mansha'atul-Ma āārif. pp. 76-77.
} 


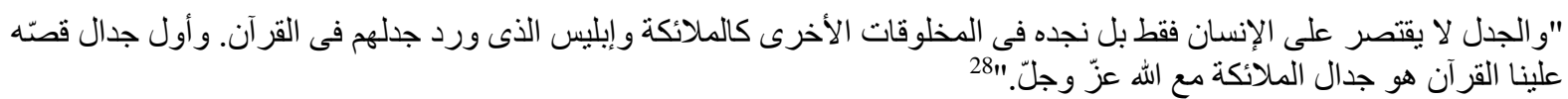

Meaning: Argumentation is not restricted to men only, rather, other creatures like the angels and 'Iblis also did participate and embark on it. The first argumentation that the Qur'ān recorded for us was the argument of the angels with Allah, the Exalt and Magnitude.

Secondly, Allah also entered into an argument with Iblis to teach the whole world lessons of indiscipline, injustice, arrogance and disobedient and side effects of all these bad acts. This incidence is quite narrated in the Qur'ān:

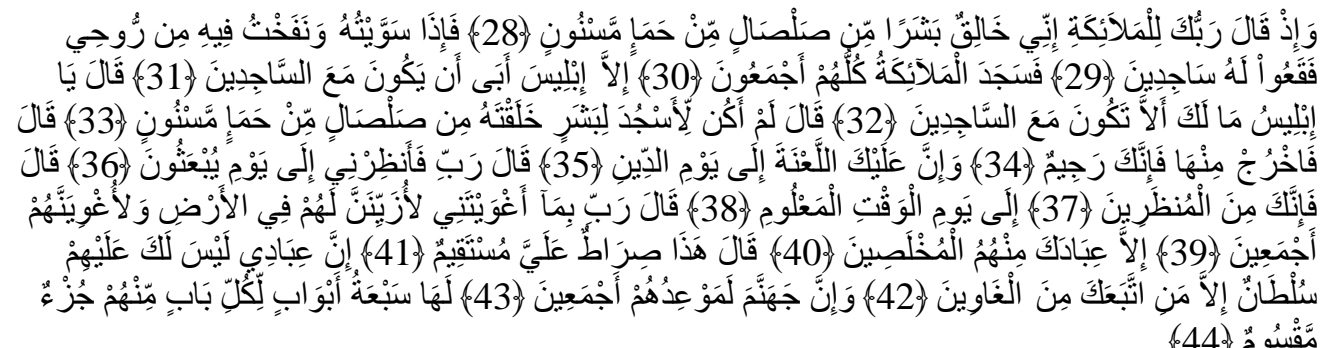

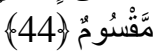

Meaning: Your Lord said to the angels, 'I will create a mortal out of dried clay, formed from dark mud. When I have fashioned him and breathed my spirit into him, bow down before him,' and the angels all did so. But not Iblis: he refused to bow down like the others. God said, 'Iblis, why did you not bow down like the others?' and he answered, 'I will not bow to a mortal You created from dried clay, formed from dark mud.' 'Get out of here!' said God. 'You are an outcast, rejected until the Day of Judgment.' Iblis said, 'My Lord, give m respite until the Day when they are raised from the dead.' 'You have respite,' said God, until the Day of the Appointed Time.' Iblis then said to God, 'Because You have put me in the wrong, I will lure mankind on earth and put them in the wrong, all except Your devoted servants.' God said, '[Devotion] is a straight path to Me: you will have no power over My servants, only over ones who go wrong and follow you. Hell is the promised place for all these, with seven gates, each gate having its allotted share of them. ${ }^{29}$

Apart from the theme of this Qur'ānic narration which is the consequence of arrogance, pomposity and violation of law and decree made by Allah that eventually led 'Iblis to the Hell as shown and appear clearly in the Qur'ānic text. A fundamental rule or ethic of argument can easily be deduced out from the narration. The ethic is to give opponent in argumentation an opportunity to express his view and point on an issue. Allah, the Most Highest and superior demonstrates a humble manner and respect for other people's view and say. He (Allah) gives all benefits of doubt to Iblis to express all what he has in mind in an exchange of ideas and evidence, without any grudges. Allah with highly respected sense of maturity He displays with Iblis makes the argument to be attractive, interesting and superb as it went on amicably throughout the debate. That shows that freedom of expression should be given to both counterparts participating in an argument, in other to ensure and achieve the goal(s) of argument at the end. Iblis is be little Allah than to be argued with. But, in launching fact and truth, nobody is being little to one another. In fact, it is general principle of argumentation that two counterparts should not feel inferior to one another, in order to be able to think very well and produce sound, valid and strong evidence. ${ }^{30}$ Thirdly, Allah also stands and argues against the Jews and the Christians in the Qur'àn to falsify their claim and prove them wrong on their untruth in an argumentation.

\subsection{Allah's Argumentation with Ahlul-Kitāb in the Qur'ān}

In not less than fifty chapters in the Qur'ān that Allah talks directly or indirectly on different issues and argues with Ahlul-Kitāb (i.e. people of the Book) in general and the Jews in particular ${ }^{31}$ in all areas of creeds, social life and politics. In the area of theology and creed, the Jews and Christians claim to be sons and the beloveds of Allah. Qur'ān reports the case thus:

\footnotetext{
${ }^{28} \mathrm{Li}^{\mathrm{c}}$ asākir.p. 15.

${ }^{29}$ Abdel Hakeem 2004.p. 163.Al-Qur'ān.Hijr15: 28-44.

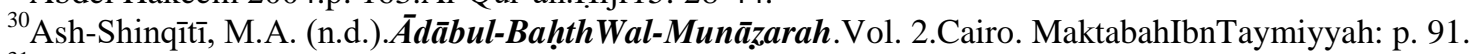

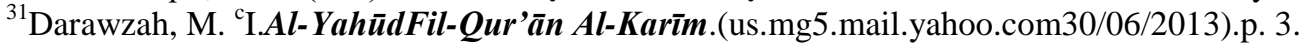




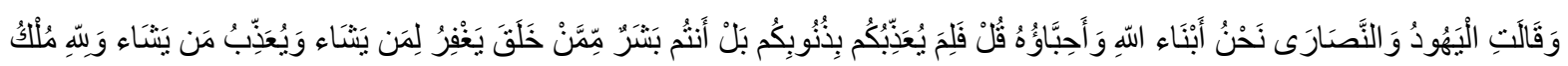

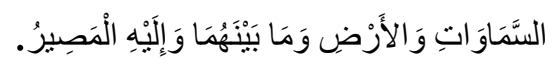

Meaning: "(Both) the Jews and the Christians say: "We are sons of Allah, and His beloved." say: "Why then doth He punish you for your sins? Nay, ye are but men,- of the men He hath created: He forgiveth whom $\mathrm{He}$ pleaseth, and $\mathrm{He}$ punisheth whom $\mathrm{He}$ pleaseth: and to Allah belongeth the dominion of the heavens and the earth, and all that is between: and unto Him is the final goal (of all)"32

The proclamation is expressed in the following wordings in the Bible that: "Thus saith the LORD, Israel is my son.Even my firstborn." 33 Also in Jeremiah: "..for I am a father to Israel, and Ephraim is my firstborn." ${ }^{34}$ But, Israel and Ephraim are both human beings they that cannot equate Allah, the Lord of universe and Creator of all creatures. They cannot withstand Allah or be His son in any way.

It is quite unfortunate for the adherents of the two religions that they build their argument on vacuum or out of solid foundation. They claim what does not exit and cannot be substantiated with reasonable point. Allah does not beget nor is He begotten. ${ }^{35} \mathrm{In}$ fact, theologically, ascribing procreation to Allah is serious case and terrible offence that its complication and gravity is explained in another chapter of the Qur'ān:

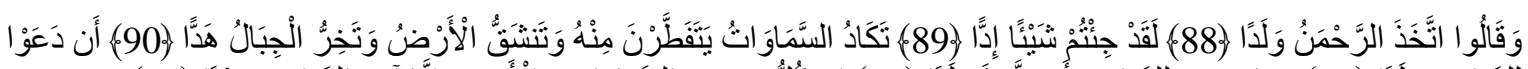

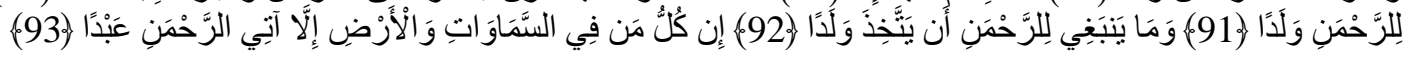

Meaning:They say: "(Allah) Most gracious has begotten a son!" Indeed ye have put forth a thing Most monstrous! At it the skies are ready to burst, the earth to split asunder, and the mountains to fall down in utter ruin that they should invoke a son for (Allah) Most Gracious. For it is not consonant with the majesty of (Allah) Most gracious that He should beget a son. Not one of the beings in the heavens and the earth but must come to (Allah) Most gracious as a servant. ${ }^{36}$

Furthermore, it is against principle of sincerity that Islam preaches for any servant to come out before his Lord and proclaim superiority that the two religions attribute that to themselves. An obedient and a serious servant can never do that. Knowing vividly that all his efforts and deeds, no matter how good is it, are always subject to acceptance or rejection, depending on the will of Allah. How can they possess such qualities when their habit was to kill the messengers of Allah sent to them for their guidance? Hayskiel was killed by a judge of Israel because he preached against their atrocities. Ash'iyā', a prophet who lived in the eight century was killed by a King of among the Jews known as Mansā. Likewise, prophet Armiyā' was also stoned to death, because, he was blaming them on their wrong and great sinful acts in the seven century. Prophet Zakariyā' was killed in his effort to safeguarded his son, Yahyā, who was also eliminated for preventing Hayrūs, who aimed at marrying his nephew. An act that is against Islamic law that all the prophets came and preached throughout their different stages ${ }^{37}$ Besides that, Allah condemns and falsifies their proclamation in a good and smooth argumentation that if they are truly family and friends of Allah, they would not be receiving punishment from Him. Then, Allah describes them as nothing but ordinary creature of Him, among others. In the verses, Allah also emphasizes His Power as big and heavy as it is, to be able to control the heavens and earths as strong as they are. The emphasis is to let them know that there are other creatures of Allah that are so mighty and remain calm and obedient worthy of notice and satisfaction of their worships than disobedient and disbelief of the people of the Books.

In addition to that, Allah cannot be seen in three that is Allah cannot be perceived as two talkless of three as in the concept of trinity upheld and believe in by the Christians. It is on the two concepts of belief in two and three gods that the holy Qur'ān demolishes:

\footnotetext{
${ }^{32}$ Ali, A. B. (trans.) 1409H/1989M.TheHolyQur'än.U. S. A. Maryland. Amana Corporation.

${ }^{33}$ Bible.Exodus. Chapter4: 22-23.

${ }^{34}$ Bible.Jeremiah.Chapter 31: 9 .

${ }^{35}$ Ali, A. B. (trans.) 1409H/1989M.TheHolyQur'ān.Al-Qur'ān.Ikhlāṣ 112: 3.

${ }^{36}$ Ibid. Al-Qur'àn. Maryam 19: 88-93.

${ }^{37}$ Hārūn, B. Ḥ. February, 2004M.Al-YahūdFil- Qur'ān. B.A. Dissertation.FPQS.USIM. Malaysia. Kuala Lumpur.
} 


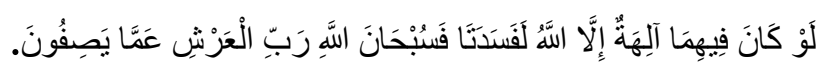

Meaning:If there were in the heavens and the earth, other gods besides Allah, there would have been confusion in both! But glory to Allah, the Lord of the Throne: (High is He) above what they attribute to $\mathrm{Him} !^{38}$

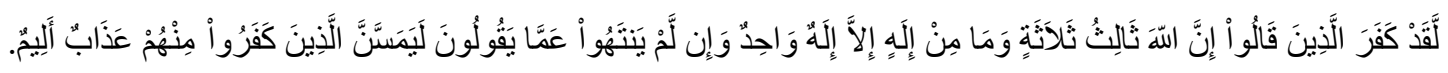

Meaning: They do blaspheme who say: Allah is one of three In a Trinity: for there is no god except one Allah. If they desist not from their word (of blasphemy), verily a grievous penalty will befall the blasphemers among them. ${ }^{39}$

On the social aspect, Qur'ān allows the Muslims to share feedings with them (people of the Book) in this injunction:

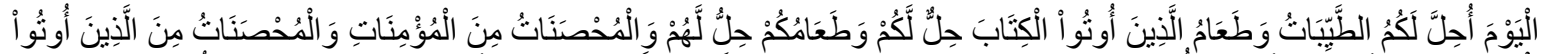

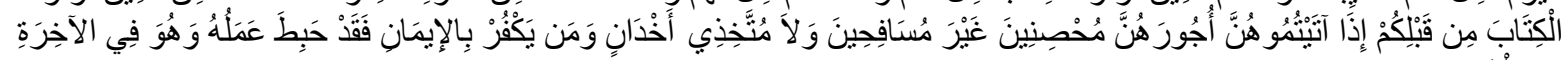

$$
\begin{aligned}
& \text { مِنَ الْخَاسِِِِينَ. }
\end{aligned}
$$

Meaning: This Day is (all) things good and pure made lawful unto you. The food of the people of the Book is lawful unto you and yours is lawful unto them. (Lawful unto you In marriage) are (Not only) chaste women who are believers, but chaste women among the people of the Book, revealed before your time,- when ye give them their due dowers, and desire chastity, not lewdness, nor secret intrigues if any one rejects Faith, fruitless is His work, and In the Hereafter He will be in the ranks of those who have lost (All spiritual good). ${ }^{40}$

The genesis of this law or the reason of revelation for this verse is that the Christians alleged the Prophet for prohibiting certain foods in consumption for himself that are allowed for them, such as pig, despite the fact that he claimed to be stepping on the foot of the religion Abraham (Ibrahim) who is the father of the three religions (Abrahamic); Jewish, Christianity and Islam. But, they should know that there are lawful and unlawful or forbidden and permissible articles in Islam, based on the on its harmfulness and harmfulless and to the body. Qur'ān pronounces that:

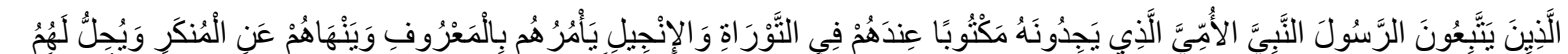

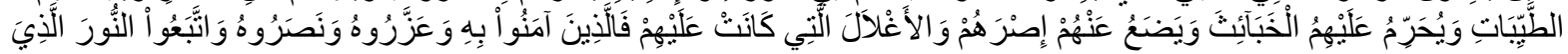

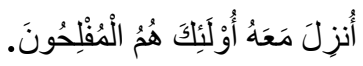

Meaning: "Those who follow the apostle, the unlettered Prophet, whom They find mentioned In their own (scriptures),- In the law and the Gospel;- for He commands them what is just and forbids them what is evil; He allows them As lawful what is good (and pure) and prohibits them from what is bad (and impure); He releases them from their heavy burdens and from the yokes that are upon them. So it is those who believe In him, honour him, help him, and follow the light which is sent down with him, - it is They who will prosper." ${ }^{41}$

The method they applied is to raise a Question to generate an argumentation. Qur'ān reports their question thus:

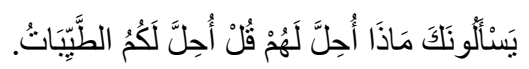

Meaning: They ask Thee what is lawful to them (as food). Say: lawful unto you are (all) things good and pure: and what ye have taught your trained hunting animals (to catch) in the manner directed to you by Allah. Eat what they catch for you, but pronounce the name of Allah over it: and fear Allah. For Allah is swift in taking account. ${ }^{42}$

\footnotetext{
${ }^{38}$ Ibid. Al-Qur'ān. Anbiyā' 21:22.

${ }^{39}$ Ibid. Al-Qur'ān. Mā'idah 5: 73.

${ }^{40}$ Ibid. Al-Qur'ān. Mā'idah 5: 5.

${ }^{41}$ Ibid. Al-Qur'ān. Al-'A 'cāf 7: 157.

${ }^{42}$ Ibid. Al-Qur'ān. Mā'idah 5: 4.
} 
From the verse, it will be understood that "all Khabā'ith (evils) are forbidden and all Țayyibāt (goods) are lawful. ${ }^{\prime 3}$ Among those things that are forbidden for consumption are thus spelt out in the Qur'ān:

Forbidden to you (for food) are: dead meat, blood, the flesh of swine, and that on which hath been invoked the name of other than Allah. that which hath been killed by strangling, or by a violent blow, or by a headlong fall, or by being gored to death; that which hath been (partly) eaten by a wild animal; unless ye are able to slaughter it (in due form); that which is sacrificed on stone (altars); (forbidden) also is the division (of meat) by raffling with arrows: that is impiety. This Day have those who reject Faith given up all hope of your religion: yet fear them not but fear Me. ${ }^{44}$

However, IbnKathīr has let us know that the word "طعام" (food) here connotes slaughtered animal. That is animals slaughtered in good manner that Islam recommends are referring to in the above verse. ${ }^{45}$

It is on political issue that Qur'ân calls attention the people of the Book to importance of abiding by the rule of Allah that cannot mislead. The law of Allah through which, stability, harmony and peace can be realized and established. Qur'ān says:

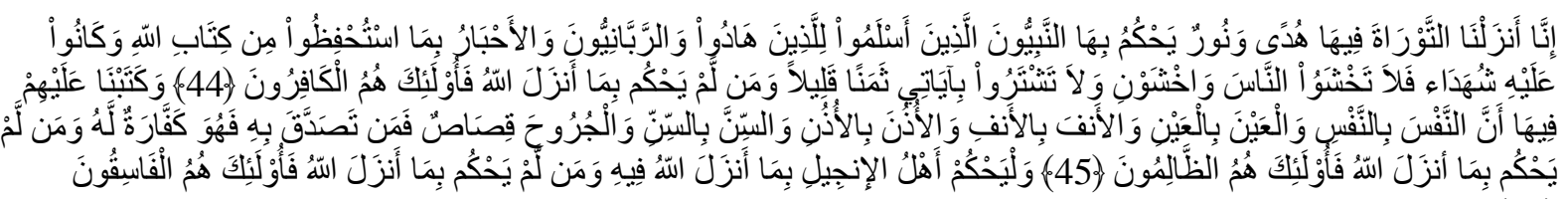

Meaning: It was we who revealed the law (to Moses): therein was guidance and light. by its standard have been judged the Jews, by the prophets who bowed (as in Islam) to Allah.s will, by the rabbis and the doctors of law: for to them was entrusted the protection of Allah.s Book, and They were witnesses thereto: Therefore fear not men, but fear me, and sell not My Signs for a miserable price. If any do fail to judge by (the light of) what Allah hath revealed, They are (no better than) Unbelievers. We ordained therein for them: "Life for life, eye for eye, nose or nose, ear for ear, tooth for tooth, and wounds equal for equal." but if any one remits the retaliation by way of charity, it is an act of atonement for Himself. And if any fail to judge by (the light of) what Allah hath revealed, they are (no better than) wrong-doers. Let the people of the Gospel judge by what Allah hath revealed therein. If any do fail to judge by (the light of) what Allah hath revealed, they are (no better than) those who rebel. $^{46}$

The bone of contention here is this phrase وَمَن لَّمْ يَكُكُ بِمَا أَنَزَلَ السّه which is used repeatedly and features thrice in three verses to mean: "If any do fail to judge by (the light of) what Allah hath revealed", such

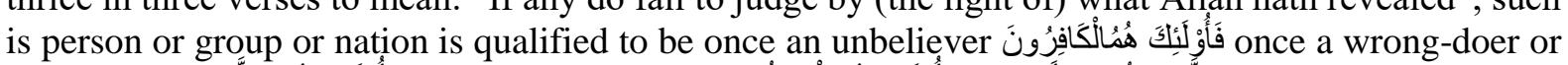

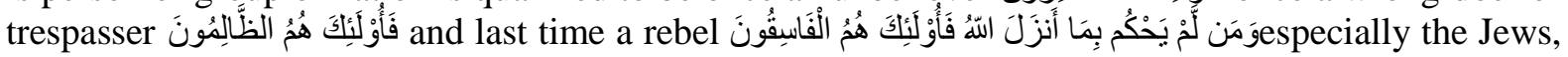
according to the Qur'ān, who have everything in written in their divine book "tawrat-Old Testament". But, instead of them to follow it, they abide by their inclinations and what will suit their whims in the Qur'ān and drop or refuse to abide by what against their caprices. ${ }^{47}$ Allah serious argues against this kind of attitude of theirs in a verse presides the above three verses that:

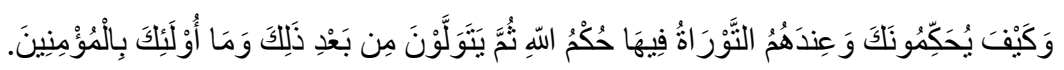

Meaning: "But why do They come to Thee for decision, when They have (Their own) law before them?- therein is the (plain) command of Allah. Yet Even after that, They would turn away. They are not (really) people of Faith." ${ }^{\text {48 }}$ This shows that, there is no basis for all evil practices of secularism and system of ruling of capitalism, socialism and communism that the other religions believe in and practicing it in Islam. All such evil practices in our political sector that are built on man-made law that

\footnotetext{
${ }^{43}$ Ṭahmāz, A.H.M. 1407H/1987M.Al-HalälWal-HarāmFūSūratul-Mā'idah. $1^{\text {st }} \quad$ Edition. Damascus. DārulQalam: p. 37.

${ }^{44}$ Ibid. Al-Qur'ān. Mā'idah 5: 3.

${ }^{45}$ IbnKathīr 1421H/2000M.Tafsīr Al-Qur'ān Al-'Az̄īm. Muhammad, Rash-shād, 'Ajmāwī, ${ }^{c}$ Abdul-Bāqī\&Qutb (ed.). $1^{\text {st }}$ Edition.Vol. 5.Jīzah.p. 77.

${ }^{46}$ Ali, A. B. (trans.).Al-Qur'ān.Mā'idah 5: 44, 45 \& s47.

${ }^{47}$ Asad Muhammad (trans.) 2013.The Message of The Qur'ān. Kuala Lumpur. Islamic Book Trust: p. 181.

${ }^{48}$ Ali, A. B. (trans.).Al-Qur'ān.Mā'idah 5: 43.
} 
is subject to criticism, changes and amendment are condemned by the Qur'ān and regarded as hukm al-Jahiliyyah. Qur'ān says:

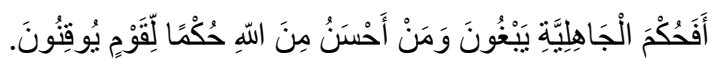

Meaning: Do they then seek after a Judgment of (the days of) ignorance? but who, for a people whose Faith is assured, can give better Judgment than Allah. ${ }^{49}$

\subsection{Involvement of the Prophets of Allah in Argumentation (Jadal)}

The purpose of Qur'ānic argumentation can be quickly derived from the fact that, almost all of the prophets of Allah embarked on it in conveying and delivering messages of Islam. For instance, prophet Nū detected the importance of using the method and he practically applied it in calling members of his household in particular and his community at large to the religion of Islam. Qur'ān reports his case thus: "They said, 'Noah! You have argued with us for too long. Bring down on us the punishment you threaten us with, if you are telling the truth'.,50

Example of prophet Ibrahim cannot be jeopardized here as well, when he realized the purpose of the method, he pragmatically embarked on it. He even laid down good instance of argumentation in the way he handled case with his father and the king of his time. He handled the matter gently with them. On his argument with Namrūd, Qur'ān narrates:

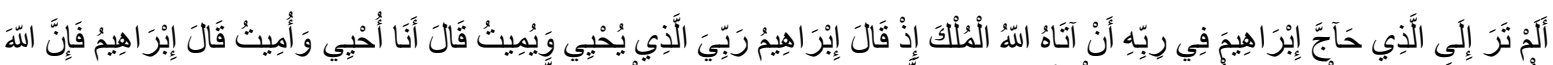

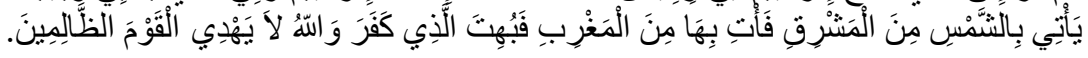

Meaning: "[Prophet], have you not thought about the man who disputed with Abraham about his Lord, because God had given him power to rule? When Abraham said, 'It is my Lord who gives life and death,' he said, 'I too give life and death.' So Abraham said, 'Allah brings the sun from the east; so bring it from the west.' The disbeliever was dumbfounded: Allah does not guide those who do evil. .51

There in this argument of prophet Ibrahim with the King a vital lesson and a good method of presentation of a case. It can also be derived from that argument that the prophet Ibrahim was ever ready and prepared for the matter. That is, he is not an ignorant of the subject of the discussion. In fact, he equipped himself and he is not an empty barrel. Without any doubt, he had enough evidences to enter into war of argumentation with the King, Namrud. ${ }^{52}$ Simply because, the concept of giving life and arresting is a clear point that does not warrant any debate between one and his soul talk less of between two persons. That is, it is not in custody of anybody, but, it is solely in the Allah's Hand. But unfortunately enough for the King, Namrūd, or out of his ignorance, he misperceived the two in defendable and indisputable attributes of Allah as apparent as they are. Prophet Ibrahim did not waste time and prolong matter when he realized that the King did not comprehend the matter at all, he just proceeded in citing another big and apparent evidence that easier to win the earth of an opponent, and that has to do with natural physical phenomenon, the sun. The prophet asked the King to bring sun out from the west, since Allah is bringing it out from the east. The King felt defeated with this untenable evidence. It was his pomposity and arrogance that led him to argue with prophet Ibrahim over his creator, Allah. Though, his argument is not over the existence of Allah, rather, it is over Allah's Supremacy, Lordship, Power and Oneness that can do and undo. This is a view upheld by SayyidQutb ${ }^{53}$ But, it should be noted that, whoever deny such handiworks of the Supreme Being, Allah, definitely, he is in variably and in directly denying His Existence without any atom of doubt. Surprisingly, one is expecting Namrūd to be grateful and thankful to Allah who selected him as a King among multimillion of people that he had control over them. Instead of him to be grateful on that, he turned back to Allah, and out of rudeness became and remained ungrateful and unthankful person. $^{54}$

\footnotetext{
${ }^{49} \mathrm{Ali}$, A. B. (trans.).Al-Qur’ān.Mā'idah 5: 50.

${ }^{50}$ Abdel Hakeem 2004.p. 138.Al-Qur'ān.Hūd 11: 32.

${ }^{51}$ Ibid. p. 30.Al-Qur'ān.Baqarah 2: 258.

${ }^{52} \mathrm{Al}-\mathrm{Q} a r n \overline{1},{ }^{\mathrm{C}} \overline{\mathrm{A}} .1427 \mathrm{H} / 2007 \mathrm{M}$. At-Tafsir Al-Muyassar.Al- ${ }^{\mathrm{c}}$ Abikan: p. 57.

${ }^{53}$ SayyidQutb.p. 297.

${ }^{54}$ Ibid.
} 
It is worthy of mentioning here as well an argument which transpired between prophet Ibrahim and the pagans of his time, including his father. The holy Qur'ān narrates this in detail in the following verses:

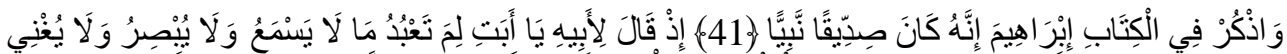

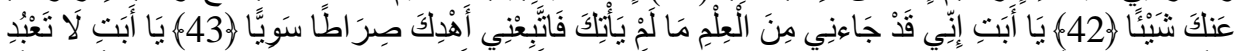

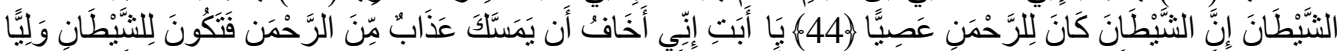

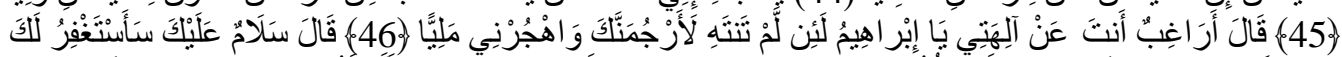

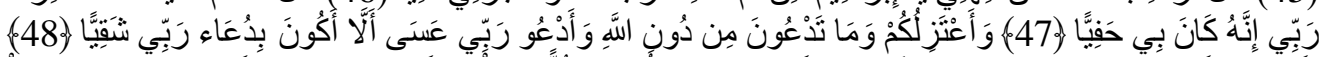

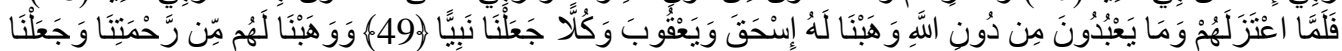

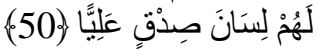

Meaning: Mention too, in the Qur'ān, the story of Abraham. He was a man of truth, a prophet. He said to his father. 'Father, why do you worship something that can neither here nor see nor benefit you in any way? Father, knowledge that has not reached you has come to me: I will guide you to an even path. Father, do not worship Satan-Satan has rebelled against the Lord of Mercy may afflict you and that you may become Satan's companion [in Hell].' His father answered, 'Abraham, do you reject my gods? I will stone you if you do not stop this. Keep out of my way!' Abraham said, 'Peace be with you: I will beg my Lord to forgive you- He is always gracious to me- but for now I will leave you, and the idols you all pray to, and I will pray to my Lord and trust that my prayer will not be in vain. ${ }^{55}$

One must cherish the method of presentation and argumentation of prophet Ibrahim who was talking before his father with all sense of humility, calmness, low voice and wings, obedience, good utterances and reaction to their words without any chaos or violent or word of shame at all. The argument is attractive and marvelous indeed, pointing at an exemplary caller to the way $(\boldsymbol{d} \overrightarrow{\boldsymbol{a}} \boldsymbol{i} \boldsymbol{y} \boldsymbol{a h})$ of Allah that prophet Ibrahim is. However, all the efforts of prophet Ibrahim here in the verses to inculcate the true belief in Greatness, Oneness and Power of Allah in the hearts of his father and his fellow colleagues in paganism were proved abortive. In other word, it is glaringly shown from the text or the verses that attention of the readers of the Qur'ān is called to theological belief and submission to the will of Allah. That is, the ambition of Prophet Ibrahim was to drive out his father and others from act of polytheism which is darkness and wrong way of course to the light of Islam, a pure, true, right, holy and only religion from Allah, sent at different ages, times, environments or continents and periods through different people known as prophets and messengers. At any time, theology is known to be very paramount and the bedrock of any religion in general and Islam in particular. It is a wonder that the argument as tough and fruitful to certain level as it is openly shown in the verses, still, it ended peacefully and mutually. That is, it did not end in wrangling and conflict. This shows the purposes of argumentation in the holy Qur'ān that, it is an instrumental to mutual understandings and peaceful co-existence towards achievement of good goals and development of every individual and a nation.

\section{AIMS AND OBJECTIVES OF JADAL IN THE QUR'ĀN:}

The only major aims and objectives of Qur'ān in using method of argumentation are to guide people to proper and right way of the true religion of Islam in all human endeavors. The argumentative method of the holy Qur'ān is not ever to persuade, impose, coerce and force its teachings on anybody; rather, it is running after human beings digestion of its messages and be self-contentment and agreement with it $\left(\mathrm{al}^{\mathrm{C}} \mathrm{Iqna}^{\mathrm{c}}\right) .{ }^{56}$ This is as a result of the fact that, Islam is a religion of peace and harmony that profoundly proclaims that, there is no compulsion in the religion. ${ }^{57}$ Therefore, it is not bound on any prophet or messenger to provoke or persuade or force the religion on anybody, as that is

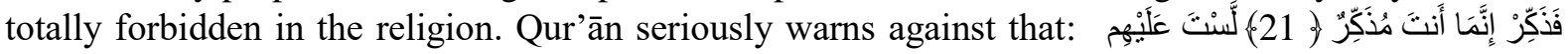

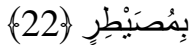

\footnotetext{
${ }^{55}$ Abdel Haleem (trans.) 2004. p.193.Al-Qur'ān. Maryam 19: 41-48.

${ }^{56}$ Abdul-Bārī, A. F. 2004. Manāhijul-BahthWaĀAāaul-Hiwārwal-Munāzarah. 1st Edition. Cairo.DārulAfāqAl- ${ }^{\mathrm{c}}$ Arabiyyah: p. 131.

${ }^{57}$ Abdel Hakeem 2004. Al-Qur'ān.Baqarah 2: 256.
} 
Meaning: "So [Prophet] warn them: your only task is to give warning, you are not there to control them. ${ }^{, 58}$ In a single word, the aims is to get people voluntarily convinced and willingly accept the religion of Islam and the teachings of the Qur'ān, starting from issue of faith, worship and moral values of Islam.

In addition to that and apart from all this, the content of the word "Jadal" and its synonyms show that, the Qur'annic argumentation is to fight against falsehood, as in this case:

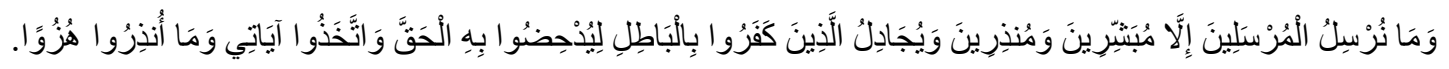

Meaning: "We only send messengers to bring good news and to deliver warning, yet the disbelievers seek to refute the truth with false arguments and make fun of My messages and warnings." $" 59$

So good so that truth can prevail. The aim of the Qur'ānic argumentation is also to kick against ignorance and its people, in order to let knowledge and its people reign. This submission can be easily understood and vividly seen in the Qur'ān thus: “..but why do you argue about some things of which you have no know nothing?"60

Not only that, some people even deny the Majesty, Existence and Signs or miracles that are pointing at the greatness of Almighty Allah. It is against this background that the holy Qur'ān gives instances and evidences to debunk their ironical stance and wrong proofs. This may be easily and quickly understood from the following Qur'ānic text:

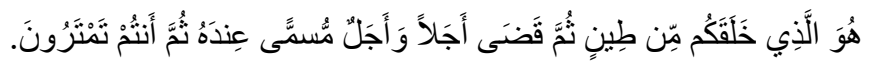

Meaning: "He is God in the one who created you from clay and specified a term [for you] and another fixed time, known only to Him; yet you still doubt!"61 The word "tamtarūn" which is a synonym to the word "Jadal" is used here to disperse the message.

In another Qur'ānic content and quotation, where argument is against those who want to deny the power of Allah in revealing His books as guidance for human beings race:

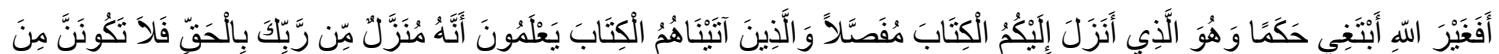

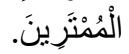

Meaning: "[Say], 'Shall I seek any judge other than God, when it is He who has sent down the Scripture, clearly explained, for you [people]?' Those to whom We gave the Scripture know that this is revealed by your Lord [Prophet] with the truth, so do not be one of those who doubt."62

The holy Qur'ān argues against hiding the truth. The truth (al-haqq) which, according to Jarīshah, ${ }^{63}$ may mean Allah Himself and His majesty, the revelations or particularly the Qur'ān, the messengers of Allah, especially the last Prophet, the death or last day, as it clearly comprehended in the Qur'ānic argumentative terms mentioned and discussed earlier. Or, as the word "haqq" connotes opposite of false and corruption, certainty, justice, absolute existence, luck, share, money, power and control, ambition, achievement, blessing, death etc in the Arabic lexicography. ${ }^{64}$ In summary, the aims and objectives of argumentation in the holy Qur'ān have been summarized in the following lines and summed up in the following good seven points; it used to be for admonition, warning, prevail of truth, affirmation of the true believers, promotion of peace and tranquility, vices eradication and prevention from its occurrence and scaring people from whim, caprices and disengagement from less concern matters or less privileged information or issues that one has no knowledge about. ${ }^{65}$ Even though, the whole arguments in the Qur'ān are for admonition and full of vital lessons that are enlightening man and guiding him to the straight path of Islam that can guarantee him success in this life in all human

\footnotetext{
${ }^{58}$ Ibid. p. 419.Al-Qur'ān.Ghāshiyat 88: 21-22.

${ }^{59}$ Ibid. p. 187. Al- Qur'ān. Kahf 18: 56.

${ }^{60}$ Ibid.p. 39.Al- Qur'ān. Āl-'Imrān 3: 66.

${ }^{61}$ Ibid.p. 80.Al- Qur'ān. Al-An'ām 6: 2.

${ }^{62}$ Ibid. p. 89.Al-Qur'ān. An'ām6: 114.

${ }^{63}$ Jarīshah, 1991.p. 29.

${ }^{64}$ See: Al-Bustān̄i, F. A. (ed.) 1986M. Munjiduṭ-Ṭullāb.Lebanon. Beirut. Dārush-Shurūq: p. 132 for the literal meanings.

${ }^{65}$ Sharqāwī, H. (nd.). Al-Jadal Fil-Qur'ān. Alexandra. Mansha'atul-Ma'ārif: p. 14.
} 
endeavors and hereafter. But notwithstanding, the subject matters of discussion of argumentative verses in the Qur'ān indicate that, there are aims and objectives for them. For example, the argumentation that occurred between Allah and the angels over the creation of Ādam was on the concept of Khilafah (vicegerency) and his role on the earth as a monitor, observer and law enforcement agent in establishing good and prohibiting bad, mischief and injustice. ${ }^{66}$

Under that as well, the levels of obedience of the angels and disobedience of Iblis were exposed by that Qur'ānic argumentation and the consequence and repercussion of the two attitudes were disclosed to serve as a lesson for all mankind, and to serve as important ways laid down for man to select which ever path suits his will and decision. All is explained under Qurānic argumentative method. Having seen this, one will be with optimism that argument in the Qur'ān serves many purposes and it has aims and objectives. Likewise, the method has some significant lessons and messages that are aiming at its conveyance to the world.

\section{CONCLUSION}

Now, from all what have been said, it is obvious that, Jadal in the Qur'ān does not mean dispute or conflict at all, rather, it is an exchange of points and proofs to stimulate truth and facts. Likewise, Jadal in the Qur'ân is not meant for fun and play, but, it has purposes and target. It is now left for every serious Muslim and responsible man to tap lessons from the argumentative method of the holy book of the Qur'ān. Furthermore, the argumentation in the Qur'ān and its methods give enlightenment on how Jadal should be, look like and how it should go on.

In addition, it should be clear that, argument is not bound and forbidden in the religion of Islam, but, it should has focus and aims of embarking on it, at any point of time. After all, the examples of good argumentation are found and seen with Allah and His prophets in general and are also experienced with prophet Ibrahim in particular.

Lastly, Qur'ān has proved that Jadal is very important in life. In fact, it is human beings natural phenomenon that man cannot do away from, simply because, man is very inquisitive. Added to that, Jadal is a method and a field of study that it requires careful study of its ethics, conditions and etiquettes. In a single word, Jadal in the Qur'ān is of multi purposes and aims. It is meaningless in the Qur'ān at all. In fact, it is used to disseminate various massages of Islam, being religious, social and political respectively. Hence, argumentation is important and is made for joke or remains in vain in the holy Qur'ân. Only that, an arguer is expected to have its ethics and etiquettes before embarking on it, because, it is believable to be an instrument of proper and mutual understanding. Above all, argumentation is real in the Qur'ān and is beyond myth and imagination or falsehood. It is an important method that Allah adopts to get people convinced about particular messages of the Qur'ān and win the earth of people that are going its missions. Not only that, but almost all the Prophets and Messengers of Allah embarked on the method to

Call people to the way of Almighty Allah.

\section{REFERENCES}

[1] Abdel Haleem, M. A. S. 2004. The Qur'ān. New York. Oxford University Press.

[2] ' Abdul-Bārī ${ }^{\mathrm{c}}$ A. F. 2004. Manāhijul-BaḥthWaĀdābul-Hiwārwal-Munāzarah. $1^{\text {st }}$ Edition. Cairo. DārulAfāq Al- ${ }^{\mathrm{c}}$ Arabiyyah.

[3] AbdusSalam, J. 2002. Al-Islam... Wa-Hịwār al-Hadarāt.Dārul-Bayān.

[4] Abus-Su ūū, M. 1391H/1971M. TafsīrAbis-Su ${ }^{c} \bar{u} d .{ }^{c}$ Aṭā, A.Q.A. (ed.). Vol.3. Riyadh. Maktabat Riyadh Al-Ḥadīthah.

[5] Abu Ameenah, B.P. September, 1997. Usool Al-Tafseer. Sharjah: p. 5.

[6] Ahamed , S. V. (trans.) 1998. The Glorious Qur'ān.Al-Azhar University. Egypt. Cairo.

[7] Ahmed, M. T. 1988M. Revelation, Rationality, Knowledge and Truth. United Kingdom. Islamic International Publications Limited.

[8] Ahamed , S. V. (trans.) 1998. The Glorious Qur'ān.Al-Azhar University. Egypt. Cairo.

\footnotetext{
${ }^{66}$ Read: Al-Qur'ān. Baqarah 2: 30 on that.
} 
[9] Al-Bayānūniyy, M. A. F. 1411H. Al-Madkhal 'Ilä ${ }^{c}$ Ilm Ad-Da ${ }^{c}$ wah. Mu'assasatAr-Risālah.

[10] Al-Bustān̄̄, F. A. (ed.) 1986M. Munjiduṭ-Ṭullāb. Lebanon. Beirut. Dārush-Shurūq.

[11] Al-Hilālī\&Khān, 1404H. The Noble Qur'ān: English Translation of the Meanings \&Commentary. K.S.A. Madinah. King Fahd.

[12] Ali, A. B. (trans.) 1409H/1989M. TheHolyQur'ān. U. S. A. Maryland. Amana Corporation.

[13] Ali, S. I. 1429H/2008M. Al-Hiwār: ManhajanWath-Thaqāfatan. $1^{\text {st }}$ Edition. Cairo. Darus-Salam.

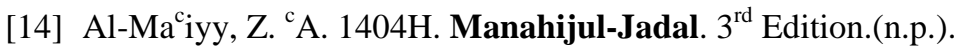

[15] Al-Qarni, ${ }^{\mathrm{A}} \overline{\mathrm{A}} .1427 \mathrm{H} / 2007 \mathrm{M}$. At-Tafsir Al-Muyassar.Al- ${ }^{\mathrm{c}} \mathrm{Abikan}$.

[16] Al-Qayn, G. A. S. 1427H/2006M. Adabul-HiwārFil-Islam. $1^{\text {st }}$ Edition. Lebanon. Beirut. Dārul-Ma ${ }^{c}$ rifah.

[17] Al-Qurțubi 1427H/2006M. Al-Jāmichi'Ahkām Al-Qur'ān. Abdul-Muhsin A.A. (ed.). $3^{\text {th }}$ Edition. Lebanon. Beirut. Mu'assasatAr-Risālah.

[18] Al- ${ }^{\mathrm{C}}$ Uthman, M. I. 1425H/2004M. Usūl Al-Jadal Wal-MunāẓarahFil-Kitab Was-Sunnah. $2^{\text {nd }}$ Edition. Lebanon. Beirut. DaruIbnHazm.

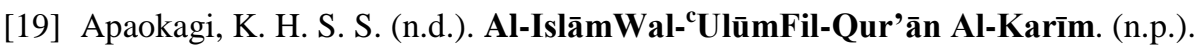

[20] Asad Muhammad (trans.) 2013.The Message of the Qur'ān. Kuala Lumpur. Islamic Book Trust.

[21] As-Sayyuti, A.R. (nd.). Al-ItqānFī̄'Ulūm al-Qur’ān.Vol. 111.K. S. A. Markaz Ad-Dirāsāt AlQur'āniyyah.

[22] Ash-Shinqītī, M.A. (n.d.). Ādābul-BaḥthWal-Munāzarah. Cairo. MaktabahIbnTaymiyyah.

[23] Denffer, Y. 1403H/1983M. 'Ulūm Al-Qur'ān. United Kingdom. The Islamic Foundation.

[24] Doi, A. I. (1404H/1984M. Sharīah: The Islamic Law. Ta-Ha Publishers, London, United Kingdom.

[25] Doi, A. I. 1981. The Cardinal Principle of Islam. Nigeria. Lagos. Islamic Publications Bureau.

[26] Fadlullahi, M. H. 1417H/1996M. Al-ḤiwarFil-Qur'ān.(5 ${ }^{\text {th }}$ Edition). Lebanon. Beirut. Dārul-Malāk.

[27] Hārūn, B. Ḥ. February, 2004M. Al-YahūdFil- Qur'ān. B.A. Dissertation.FPQS.USIM. Malaysia. Kuala Lumpur.

[28] $\mathrm{Ibn}^{\mathrm{c}} \bar{A}$ shur , M. T. 1984. At-TahrīrWat-Tanwīr. Ad-Dar At-Tunisiyyah.

[29] IbnKathīr 1421H/2000M.Tafsīr Al-Qur'ān Al-'Azīm. Muhammad, Rash-shād, ${ }^{\mathrm{c}}$ Ajmāwī, ${ }^{\mathrm{c}}$ AbdulBāqī̊Qutb (ed.). $1^{\text {st }}$ Edition.Jīzah.

[30] IbnManẓūr, 1412H/1992M. Lisānul- ${ }^{\mathbf{c}}$ Arab. $1^{\text {st }}$ Edition.Vol. 2. Lebanon. Beirut. Dār-Ṣādir.

[31] Jarīshah, 'A.1412H/1991M.Adabul-HiwārWal-Munāzarah.2nd Edition.Dārul-Wafā' .

[32] Licasakir, Y. U. 2005.Al-Jadal F̄̄ al- Qur'ān-Khașā’iṣuhuWadilālātuhu. M. A. Dissertation. Algeria University.

[33] Philips, A. B. September, 1997. Usool Al-Tafseer. Sharjah.

[34] Parker, R. 2004. Critical Thinking. $7^{\text {th }}$ Edition. Chico. Califorma State University.

[35] Qattān, M. 1423H/2002M. MabāḥithF̄̄'Ulūm Al-Qur’ān.12th Edition. Cairo. MaktabahWahbah.

[36] Qutb, S. (1417H/1996M. FīZilāl al-Qur'ān.25 ${ }^{\text {th }}$ Edition.Vol. 4. Cairo. Darush-Shurūq.

[37] Sharqāwī , H. (nd.). Al-Jadal Fil-Qur’ān. Alexandra. Mansha'atul-Ma āāif.

[38] Ṭahmāz, A.H.M. 1407H/1987M.Al-HalālWal-HarāmF̄̄Sūratul-Mā'idah.1 ${ }^{\text {st }}$ Edition. Damascus. Dārul-Qalam.

[39] Vicker, A. S. (trans.) 1999. Interpretation of the Meaning of the Glorious Qur'ān. Malaysia. Kuala Lumpur. TR Group of Company.

[40] Wurn, H. 1998. Oxford Word Power. New York. Oxford University Press.

[41] Zurqānī, M. A. (nd.). Manāhilul- 'IrfānFī- 'Ulūm Al-Qur’ān. Vol. I. Cairo. Dārul-'Ihyā' 1-Kutub 1${ }^{\mathrm{c}}$ Arabiyyah.

\section{AUTHORS' BIOGRAPHY}

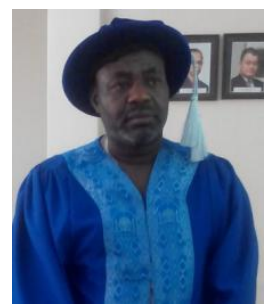

Dr. Bello, Muhammad Kamal-deen is a Lecturer of Islamic Studies who obtained his Ph. D in Qur'anic Studies (Ulumul-Qur'an) from Faculty of Qur'an and Sunnah Studies, Universiti Sains Islam Malaysia (Islamic Science University, Malaysia). He worked as a Lecturer with Department of Islamic Studies, School of Arts and Islamic Studies, Kwara State College of Arabic and Islamic Legal Studies, Ilorin, Nigeria (2003-201) where he taught various discipline of Islamic Studies at both levels of Diploma (2003-2015) and Degree (2015-2017), such as Islamic Jurisprudence, Theology, Thought and Movement, Tajwid and Qira'aat etc. He served in the capacity of H.O.D. Islamic Studies from 2007-2010, 2010-2012 and 2015-2017 respectively. He also 
helped in teaching Islamic Studies at Degree level in Nigerian College of Education (NCE), Ilorin, Kwara State from 2006-2012. Presently, he took appointment as a Lecturer of Islamic Studies with National Open University, Nigeria (NOUN) in 2017. He is subject Master of Tafsir, Inter-Religious Dialogue, Islamic Political Institutions, Islamic Movements etc.

Citation: Muhammad Kamal-Deen Bello. "Argumentation (Jadal): An Inevitable Method of Expression in the Qur'ān: Purpose and Aims. "International Journal of Humanities Social Sciences and Education (IJHSSE), vol 4, no. 12, 2018, pp. 107-120. doi: http://dx.doi.org/10.20431/2349-0381.0412011.

Copyright: (c) 2018 Authors. This is an open-access article distributed under the terms of the Creative Commons Attribution License, which permits unrestricted use, distribution, and reproduction in any medium, provided the original author and source are credited. 